\title{
Archaeological Investigation of the Gristmill at Mission San Jose y San Miguel de Aguayo, San Antonio, Texas
}

Andrew J. Scease

Center for Archaeological Research

Kevin J. Gross

Center for Archaeological Research

Follow this and additional works at: https://scholarworks.sfasu.edu/ita

Part of the American Material Culture Commons, Archaeological Anthropology Commons, Environmental Studies Commons, Other American Studies Commons, Other Arts and Humanities Commons, Other History of Art, Architecture, and Archaeology Commons, and the United States History Commons

Tell us how this article helped you.

This Article is brought to you for free and open access by the Center for Regional Heritage Research at SFA ScholarWorks. It has been accepted for inclusion in Index of Texas Archaeology: Open Access Gray Literature from the Lone Star State by an authorized editor of SFA ScholarWorks. For more information, please contact cdsscholarworks@sfasu.edu. 
Archaeological Investigation of the Gristmill at Mission San Jose y San Miguel de Aguayo, San Antonio, Texas

\section{Creative Commons License}

\section{(c) (1) \&}

This work is licensed under a Creative Commons Attribution-NonCommercial 4.0 International License 


\title{
Archaeological Investigation of the Gristmill at Mission San José y San Miguel de Aguayo, San Antonio, Texas
}

\author{
Andrew J. Scease and Kevin J. Gross
}

Robert J. Hard and C. Britt Bousman Principal Investigators

Texas Antiquities Permit No. 1761

Ccopyright 1998

Center for Archaeological Research

The University of Texas at San Antonio

Archaeological Survey Report, No. 272 
The following information is provided in accordance with the General Rules of Practice and Procedure, Chapter 41.11 (Investigative Reports), Texas Antiquities Committee:

1. Type of investigation: Survey

2. Project name: San José Gristmill

3. County: Bexar

4. Principal investigators: Robert J. Hard and C. Britt Bousman

5. Name and location of sponsoring agency: National Park Service, San Antonio Missions National Historical Park, San Antonio, Texas

6. Texas Antiquities Permit No.: 1761

7. Published by the Center for Archaeological Research, The University of Texas at San Antonio, 6900 N. Loop 1604 W., San Antonio, Texas 78249-0658, 1998

A list of publications offered by the Center for Archaeological Research is available. Call (210) 458-4378; write to the Center for Archaeological Research, The University of Texas at San Antonio, 6900 N. Loop 1604 W., San Antonio, Texas 78249-0658; e-mail to car@lonestar.utsa.edu; or visit CAR's web site at http://www.csbs.utsa.edu/research/car/index.htm. 


\begin{abstract}
The Center for Archaeological Research (CAR) of The University of Texas at San Antonio undertook archaeological investigations of the gristmill and adjacent areas at Mission San José y San Miguel de Aguayo in San Antonio, Texas, in mid-December 1996. The work was completed in advance of work proposed for making the mill operational. The restoration required that six areas be examined: a set of limestone staircases crossing the acequia near the mill, the interior of the mill's sluice, the forebay, the floor of the mill vault, a small portion of the mill race, and a stone-lined pit that is presumed to be either a tanning or sugar processing vat east of the mill.
\end{abstract}




\section{Table of Contents}

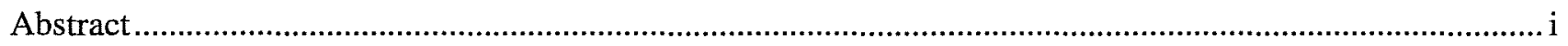

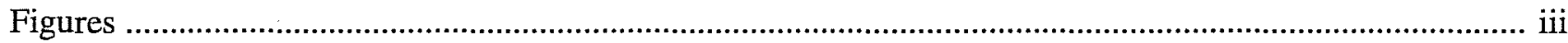

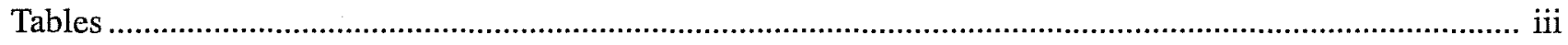

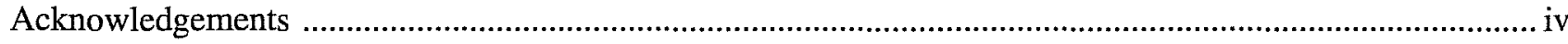

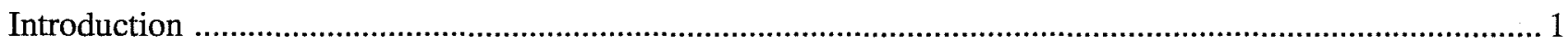

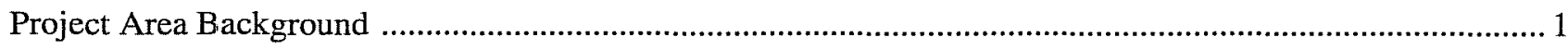

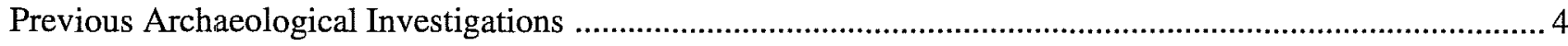

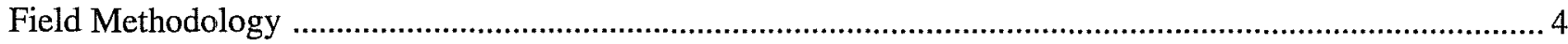

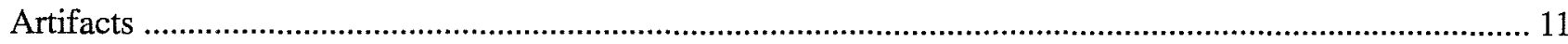

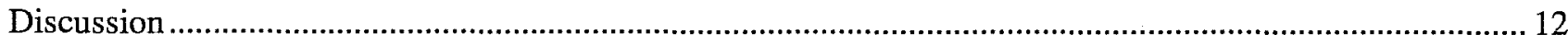

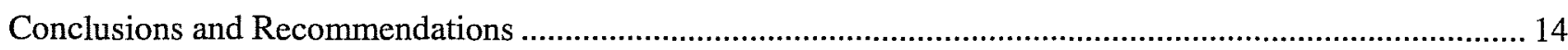

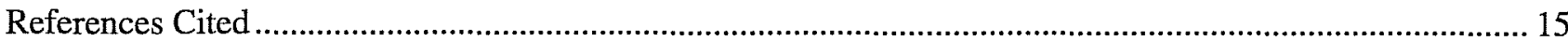




\section{Figures}

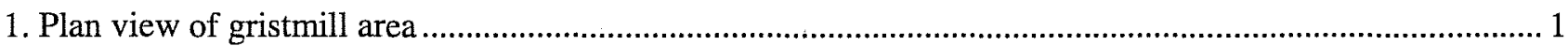

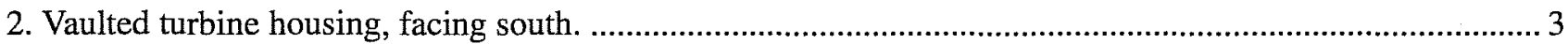

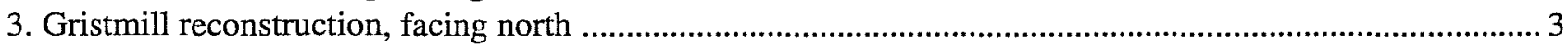

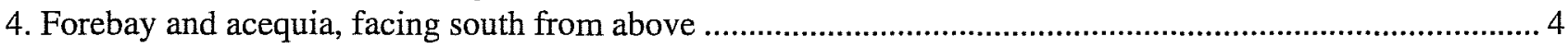

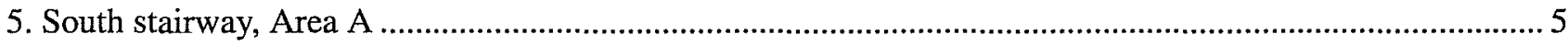

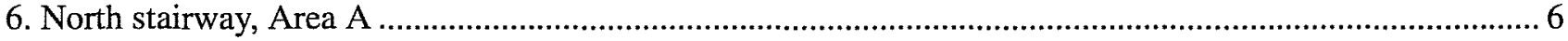

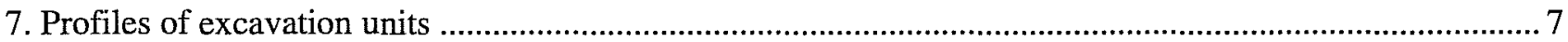

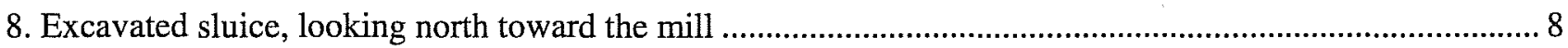

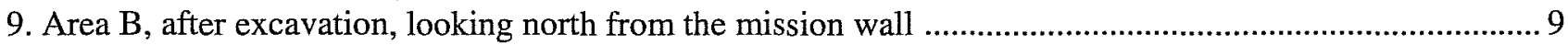

\section{Tables}

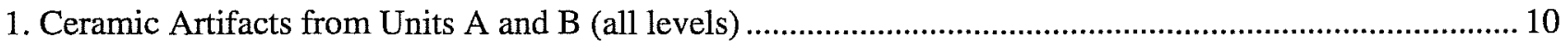

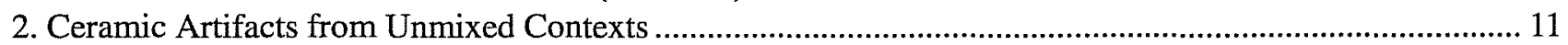




\section{Acknowledgments}

Thanks are extended to the CAR field crew: Maureen J. Brown, Donna Edmondson, Owen A. Ford, Ed Johnson, Bruce K. Moses, and Robert R. Rector. Anne A. Fox's assistance in the field and laboratory is greatly appreciated. Johanna Hunziker is also thanked for her time in analyzing the faunal remains. Thanks also to Cynthia L. Tennis, the small projects coordinator at CAR, for completing the pre-fieldwork and for reviewing preliminary drafts of this report. We are grateful to Mark Chavez and James Oliver, both from the National Park Service (San Antonio Missions National Historic Park), for sharing their observations and knowledge. Thanks also go to Bruce Moses and Fernando Valenzuela for drafting the figures and to Marcie Renner for her editing skills. Robert J. Hard, director of CAR and principal investigator for the project, is thanked for his assistance and guidance throughout the project. 


\section{Introduction}

The Center for Archaeological Research (CAR) of The University of Texas at San Antonio undertook archaeological investigations of the gristmill and adjacent areas at Mission San José y San Miguel de Aguayo in San Antonio, Texas, in mid-December 1996. The work was completed in advance of work proposed for making the mill operational. The partial restoration - only a small segment of the acequia will be used with constantly recycled water-is being conducted by Los Compadres and the National Park Service (NPS), with technical assistance from Overby Descamps Engineers. The restoration required that the following six areas be examined (Figure 1): a set of limestone staircases crossing the acequia near the mill, the interior of the mill's sluice, the forebay, the floor of the mill vault, a small portion of the mill race, and a stonelined pit that is presumed to be either a tanning or sugar processing vat east of the mill. The original (i.e.,
Spanish colonial) acequia channel was identified in units excavated in association with the staircases.

Excavation of the sluice was expanded to include areas around the channel; wall remnants were encountered in these units. No intact Colonial or post-Colonial deposits were identified in the units associated with the sluice.

\section{Project Area Background}

\section{History}

Only a brief overview of Mission San José's general historical development is presented here. Habig (1968a, 1968b) and Day (1965:129-164) should be consulted for more complete histories of the mission. Similarly, Ivey et al. (1990a, 1990b) have described

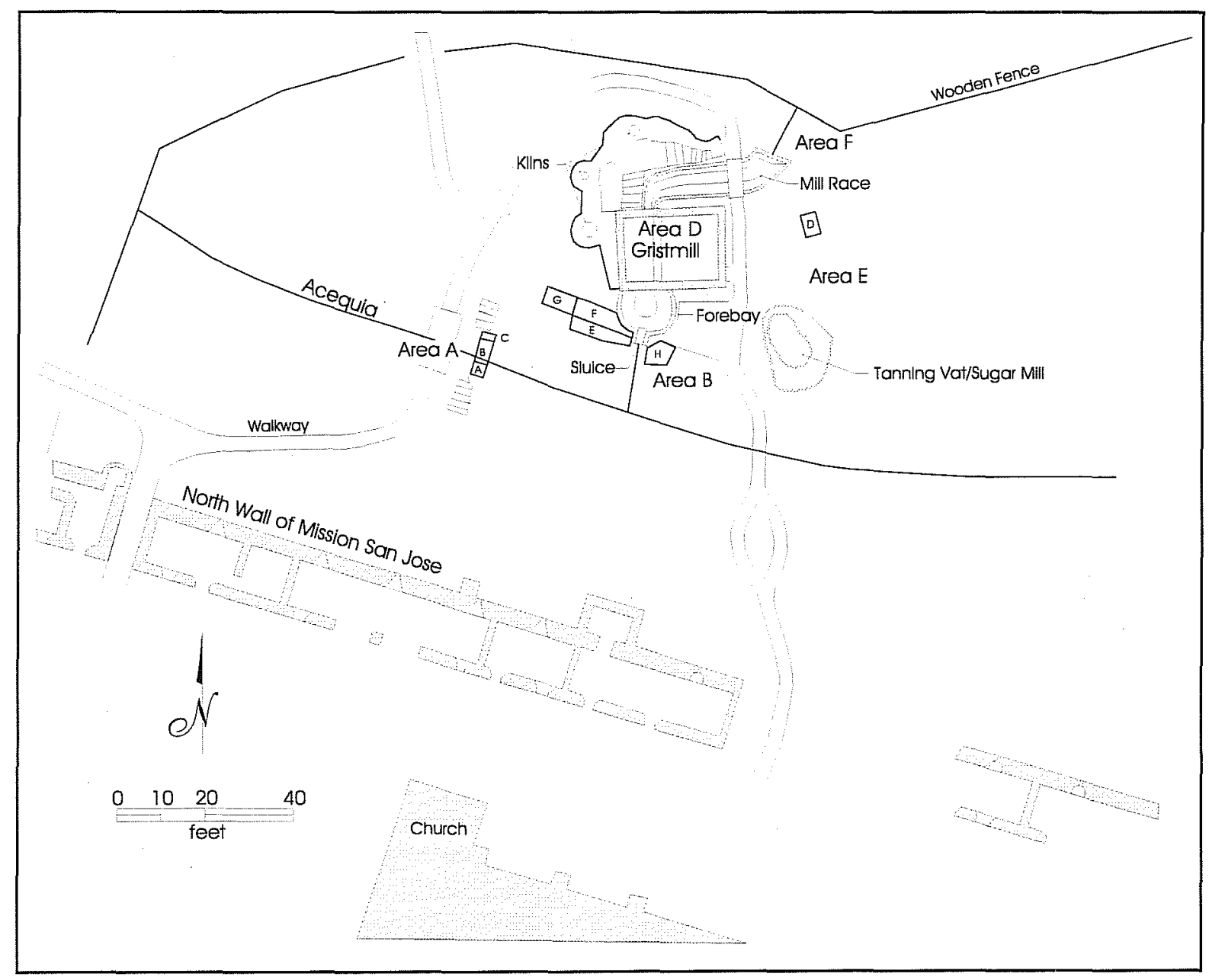

Figure 1. Plan view of gristmill area. 
the architectural history of the mission. Habig (1978, 1983) and Leutenegger and Casso (1990) provide rich descriptions of San José and its inhabitants. Bolton (1915), Chipman (1992), Jones (1979), and Schuetz (1980) also provide useful descriptions of the Spanish colonial period in San Antonio and Texas.

Mission San José was originally established in 1720 on the east bank of the San Antonio River about 3.5 miles south of Mission San Antonio de Valero (the Alamo). The mission was moved to its present location on the west side of the river between 1724 and 1727. Campbell and Campbell (1985:46-59) believe that members from at least 21 Native American groups lived at San José at various times during the Colonial period. Many of the early records from San José have been lost, however, so the actual number of groups that lived at the mission might be much greater. The Native American population at San José fluctuated radically throughout the Colonial period. In the late 1730 s, as many as 300 Indians lived at the mission. Epidemics in 1739 and 1740 killed many Indians and caused others to flee. The population quickly increased thereafter, and by 1768 the number of Indian neophytes probably peaked at about 350 persons. The Indian population then began a gradual decline until secularization. The last census of San José in 1815 recorded only 49 Indians (Habig 1968b:270).

In 1749 a visitor to the mission reported that the granary, friary, stone houses for the Indians, and a large church constructed of adobe had been completed (Habig 1968b:116). This first church was destroyed in 1768 and foundations for a new stone church were laid in the same location. The second church, which still stands - albeit partially reconstructed in the nineteenth and twentieth centuries-was completed in 1782. Ivey et al. (1990a) believe that Mission San José was an unwalled pueblo until about 1758-1768. Increasing attacks by hostile Indian tribes, most notably the Apache and Comanche, forced the construction of the defensive walls.

Habig (1968a:100) believes that the mill was constructed between 1789 and 1794. Indeed, the first mention of a mill at San José was included in a comprehensive inventory of the mission completed in 1794, "a water mill for grinding wheat that is operated by a running stream but no dam" (Habig et al. 1983:131). It is believed that Fr. Pedrajo, the missionary in charge of San José at the time, directed the con- struction of the flour mill on the orders of Governor Domingo Caballo in 1778. Caballo wanted wheat, barley, and beans planted in the mission fields in addition to corn (Habig 1968a:100; Ivey et al. 1990:138). Habig (1968a:100) suggests that wheat had not been raised in previous years because "the Indians did not care for it."

A few references suggest that the mill was operational until at least the middle of the nineteenth century. Two inventories of the mission completed in 1809 mention that the mill was still grinding wheat (Habig et al. 1983:264, 274). A novel, Daughter of Tehuan, published in 1866, provides a detailed description of the mill (Hoermann 1932:29, 95). The book's author, Reverend P. Alto S. Hoermann, was a Benedictine father who resided at Mission San José from ca. 18591864 (Hoermann 1932:4). Although a work of fiction, Hoermann's descriptions of features and events seem generally correct. Therefore, it is assumed that enough of the mill's structure was still standing for Hoermann to make his observations. References to the mill from the late nineteenth century have not been located.

Clark (1978:41) reports that the mill was encountered in 1934 by workmen cleaning the acequia. The mill complex was excavated and reconstructed by the Works Progress Administration (WPA), under the general direction of Harvey P. Smith, Sr. (Smith 1935:1213), as a part of the larger reconstruction of the mission. Photographs (Figures 2, 3, and 4) taken during excavations associated with the reconstruction suggest that the entire area had been severely disturbed before and during reconstruction. Figure 3 reveals that a large portion of the acequia's north bank immediately south of the mill was removed during restoration. Figures 2 and 4 show that the forebay and vaulted turbine room were intact under the surface.

The WPA reconstruction followed plans designed by Ernst Schuchard (then an employee of Pioneer Flour Mills in San Antonio). In short, Schuchard's research culminated in the mill that exists today: water from the acequia would have been directed into the forebay through a sluice. The sluice apparently would have had a mechanism (most probably a wooden gate) to control the flow of water into the forebay. An aperture near the bottom of the forebay would have discharged water into the vault directly onto the mill turbine. The mill wheel itself was horizontal with a series of angled paddles radiating from the shaft. Wa- 


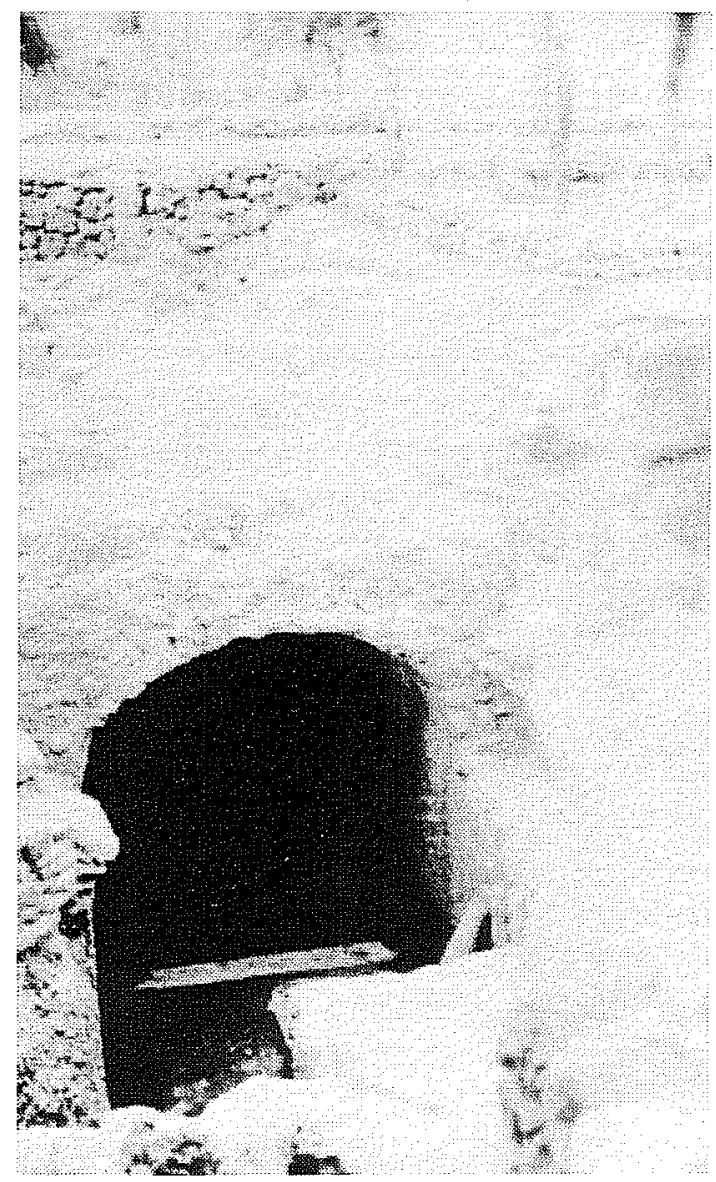

Figure 2. Vaulted turbine housing, facing south. Courtesy Daughters of the Republic of Texas Library. ter entering the vault would have struck the paddles with enough force to turn the grindstones (Schuchard 1934:9). An engineer who studied the mill at San José concluded that the forebay's design ensured that water entered the vault and struck the turbine at a constant rate. The overall quality of the flour is improved when the number of revolutions per minute of the millstones can be kept at a uniform rate (Czibesz 1955:4).

The actual milling would have occurred in the structure above the vault. The shaft would have entered the mill room through a hole in the floor (which Smith located) and connected to two stones: the top stone was rotated by the movement of the turbine below, while the bottom stone remained stationary. The height of the top stone could be adjusted by a series of connected levers extending down into the vault. Grains were placed into a hopper and fed through the center of the stone to the grinding surface. The ground meal was discharged at the outer edge of the stones and was collected in a wooden casing surrounding the stones (Schuchard 1934:9). While Smith intended for the final reconstruction of the mill to be functional, it is unclear if it ever was (Smith 1935:13); a report from 1955 says that the mill was not operational at that time (Czibesz 1955:7).

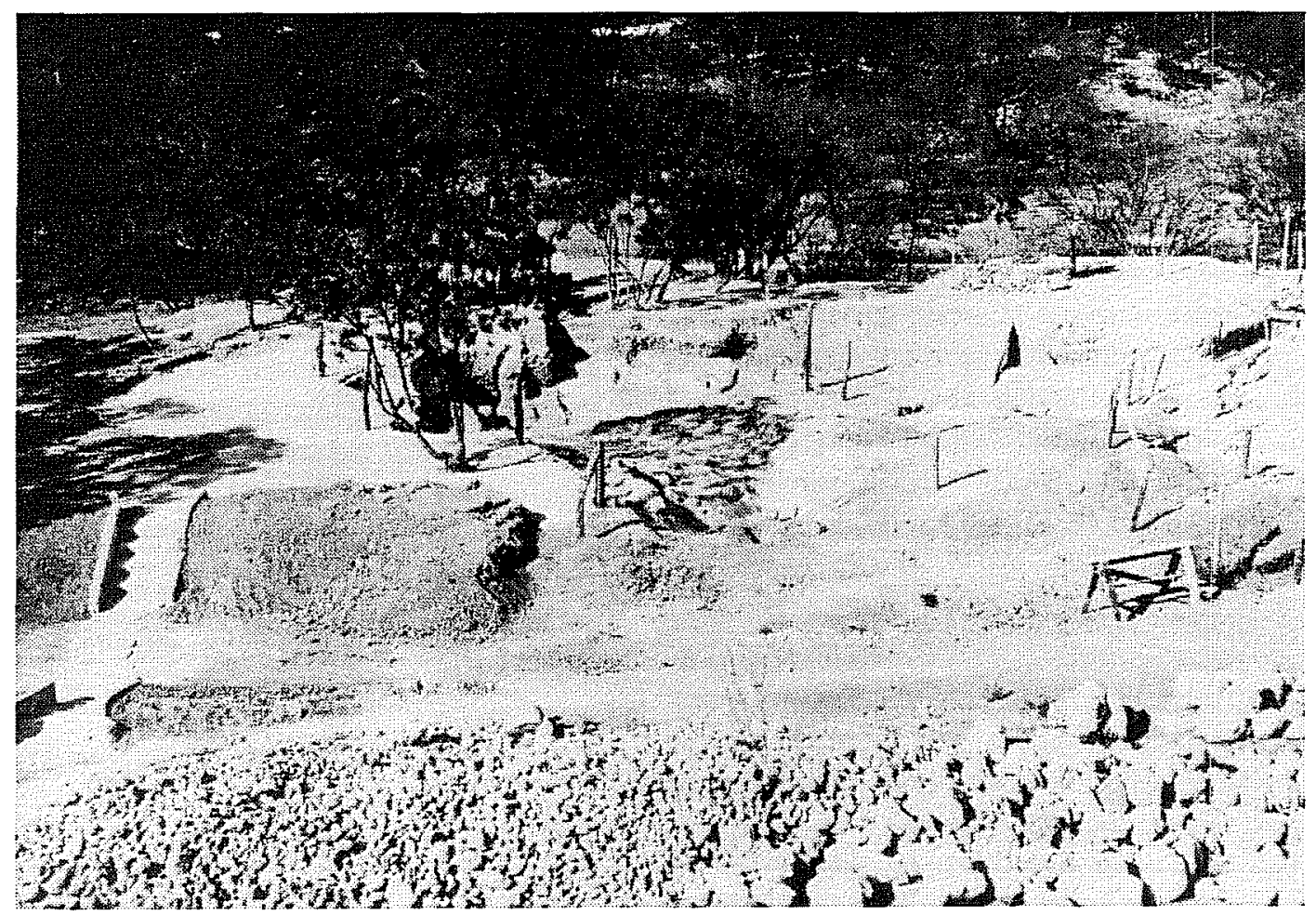

Figure 3. Gristnill reconstruction, facing north. Courtesy San Antonio Missions NHP. 


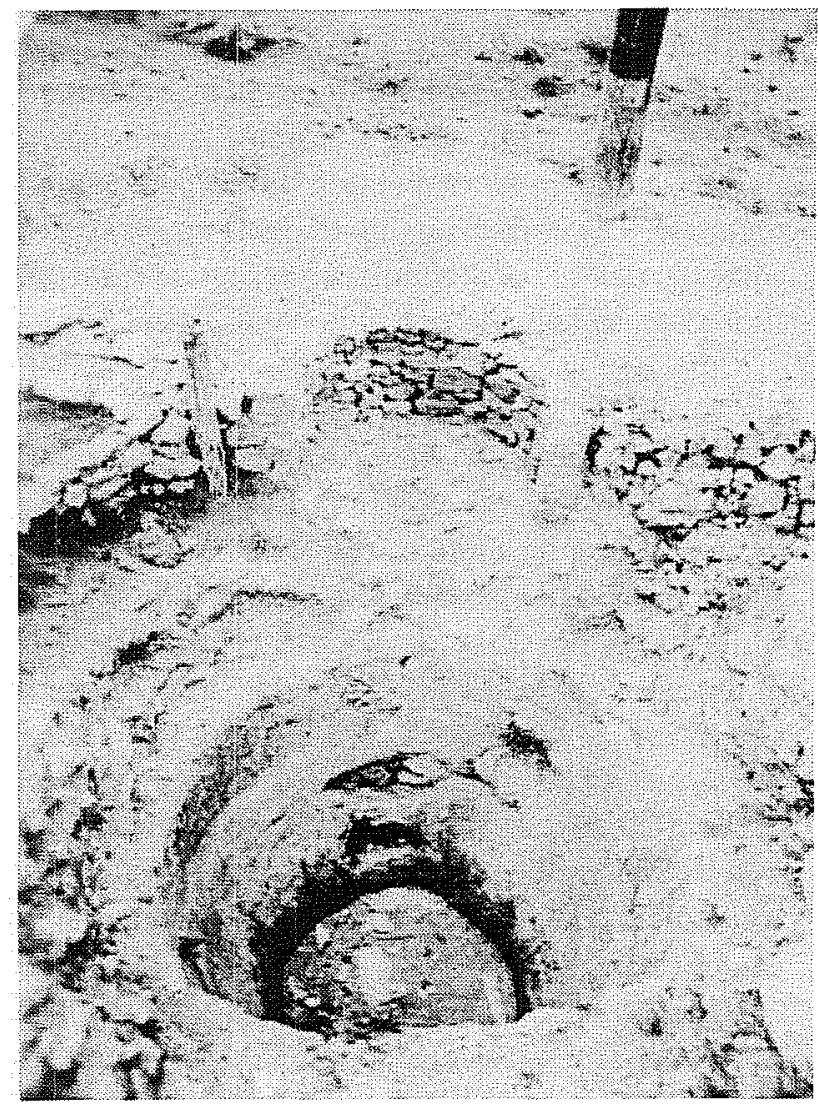

Figure 4. Forebay and acequia, facing south from above. Courtesy San Antonio Missions NHP.

\section{Previous Archaeological Investigations}

A number of archaeological investigations have been completed at Mission San José since the early 1970s, as summarized by Hard et al. (1995). Only Clark (1978) investigated areas near the mill. Clark excavated eight test pits in the northern portion of the compound, both inside and outside, and two of these units, Test Pits 4 and 8, were within the boundaries of the current project area. All the archaeological work performed at San José, including Clark's excavations, has been limited in area and scope to testing projects completed in advance of construction activities.

Schuetz (1970) excavated several shallow trenches throughout the park in preparation for the construction of a sprinkler system. In 1969 and 1970, D. Fox excavated units near the north wall of the church and convento and along the north wall of the compound in advance of sewer and electrical trenches (Fox et al. 1970). The southwest and southeast corners of the compound were tested by Roberson and Medlin (1976) in 1974 and 1976 prior to the construction of a new office and sanitary facilities and in preparation for the construction of a visitors' center, respectively. Clark and Prewitt (1979) excavated five test pits along the outside of the granary's western wall prior to the installation of a drainage system. In 1984, Henderson and Clark (1984) recorded a possible corral, a previously disturbed human burial, and a portion of a Colonial acequia south of the mission beneath Napier Avenue (Park Road 39). A proposed sewer line outside of the mission's west wall necessitated investigations by Hafernik and Fox (1984). They located a post-Colonial well in their test trench. In 1991 Fox and Cox (1991) located the Acequia Madre and a related lateral ditch with 11 backhoe trenches on the east side of the mission.

In 1993 CAR archaeologists undertook archaeological investigations at Mission San José to assess the impact of a proposed visitors' center (Hard et al. 1995). The entire interior compound of the mission was tested to identify Spanish colonial deposits. Additional units were excavated in the southeast gate and south of the mission wall. In 1996 Tennis (1997) reinvestigated the southeast gate area with a hand-excavated trench.

\section{Field Methodology}

Excavations for this project were limited to the removal of predominantly post-1934 fill from the mill and associated features, including the interiors of the sluice and the forebay, the mill vault floor, and the north mill race (Figure 1). A set of stairs east of the mill, on the north and south banks of the acequia, were also exposed. A 2-x-3-ft unit was hand excavated in the circular pit referred to as the "tanning vat/sugar processing area" so that researchers from the NPS could collect residue samples to determine the feature's function. Only the matrix from the stairs and a unit excavated east of the sluice (Unit $\mathrm{H}$ ) was screened. Elevations for the entire area were recorded with an electronic distance measuring instrument. Brief descriptions of the excavation units and soils are provided below.

\section{Area A (Features 1 and 2)}

An arbitrary datum for Area A (586.53 ft amsl) was placed on the southwest corner of the uppermost stair on the south side of the acequia. Artifacts from the 


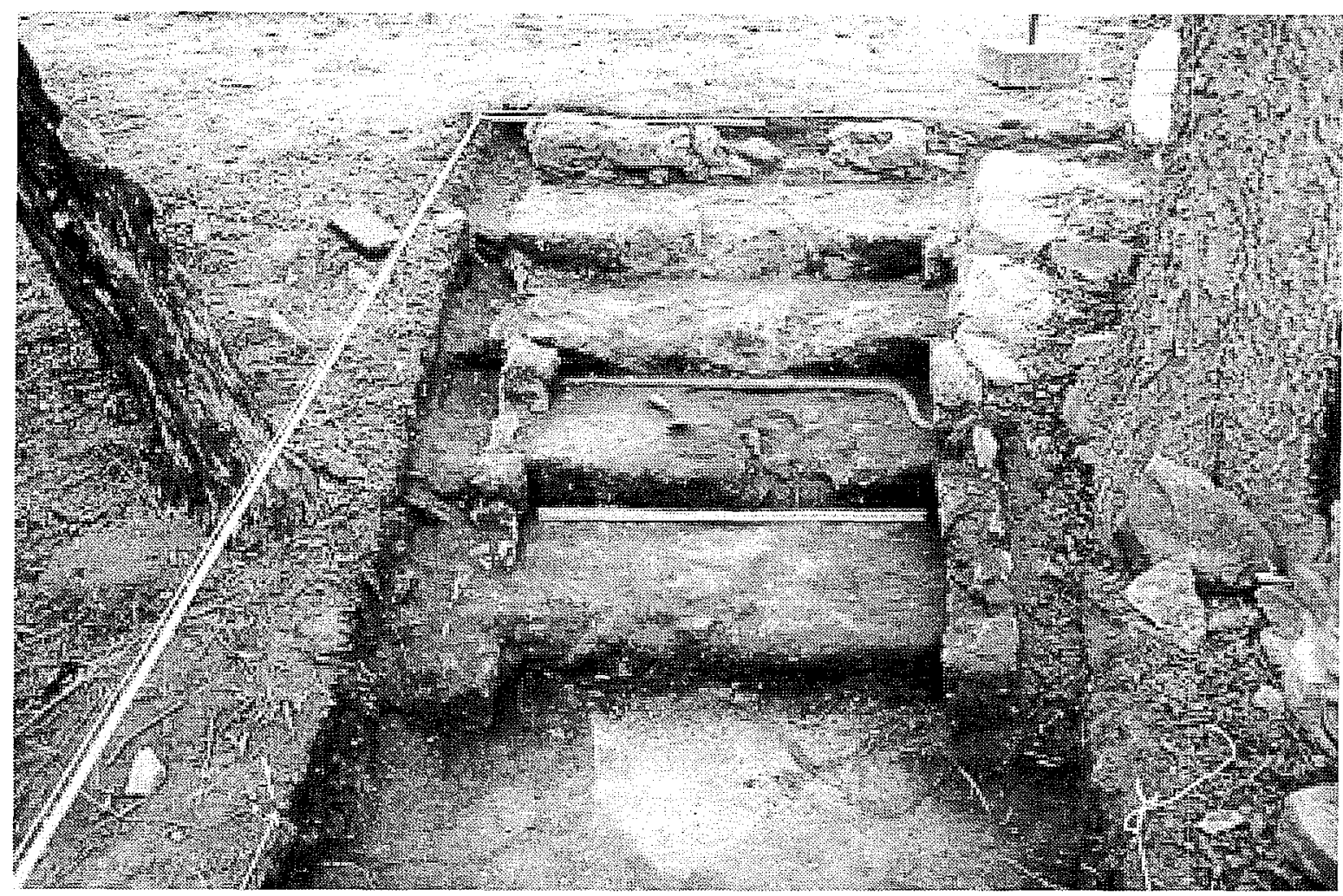

Figure 5. South stairway, Area A.

limestone stairs on the south (Feature 1) and north sides (Feature 2) of the acequia were collected separately. Along both outside edges of the stairs a course of stone was placed and cemented with a loose sandy mortar. Both sets of stairs were fairly uniform in size. Each step was approximately 40 inches wide (excluding the single course of stone on each side), six to seven inches thick, and between 14 and 20 inches deep.

The first two steps on the south side were fragmented; the first step apparently as the result of grounds-keeping activities and erosion, and the second from erosion only (Figure 5). The next three steps were better preserved, showing only slight damage from erosion. A triangular flagstone, with a maximum width of 27 inches and a maximum length of 24 inches, was identified after the last step at the bottom of the south stairs.

The stairs on the north side of the acequia were also cleared of overburden. Only four steps were identified on this side (Figure 6). A photograph taken during the WPA reconstruction (Figure 3) suggests that in ca. 1934 there were five steps, so it appears the topmost step is missing. The northern staircase was relatively less intact and less uniform than the southern staircase. The intrusion of large roots from a nearby hackberry tree are probably responsible for the fragmentation of the north stairs. The topmost remaining step had been repaired at an unknown time with Portland cement. The other steps were in pieces, with 50 percent of the third step missing. Besides the topmost step, all the steps on the north side of the acequia were constructed with the same loose, sandy mortar found in the south stairs.

Three test units-Units A, B, and C-were excavated in Area A between the two sets of stairs in the acequia's existing bed (Figure 1). These units were excavated in six-inch levels and the material screened through 1/4-inch mesh. A local datum for all three units was established in the southwest corner of Unit A at 584.63 $\mathrm{ft}$ amsl (25 inches below the Area Datum and twoinches above the existing ground surface). 


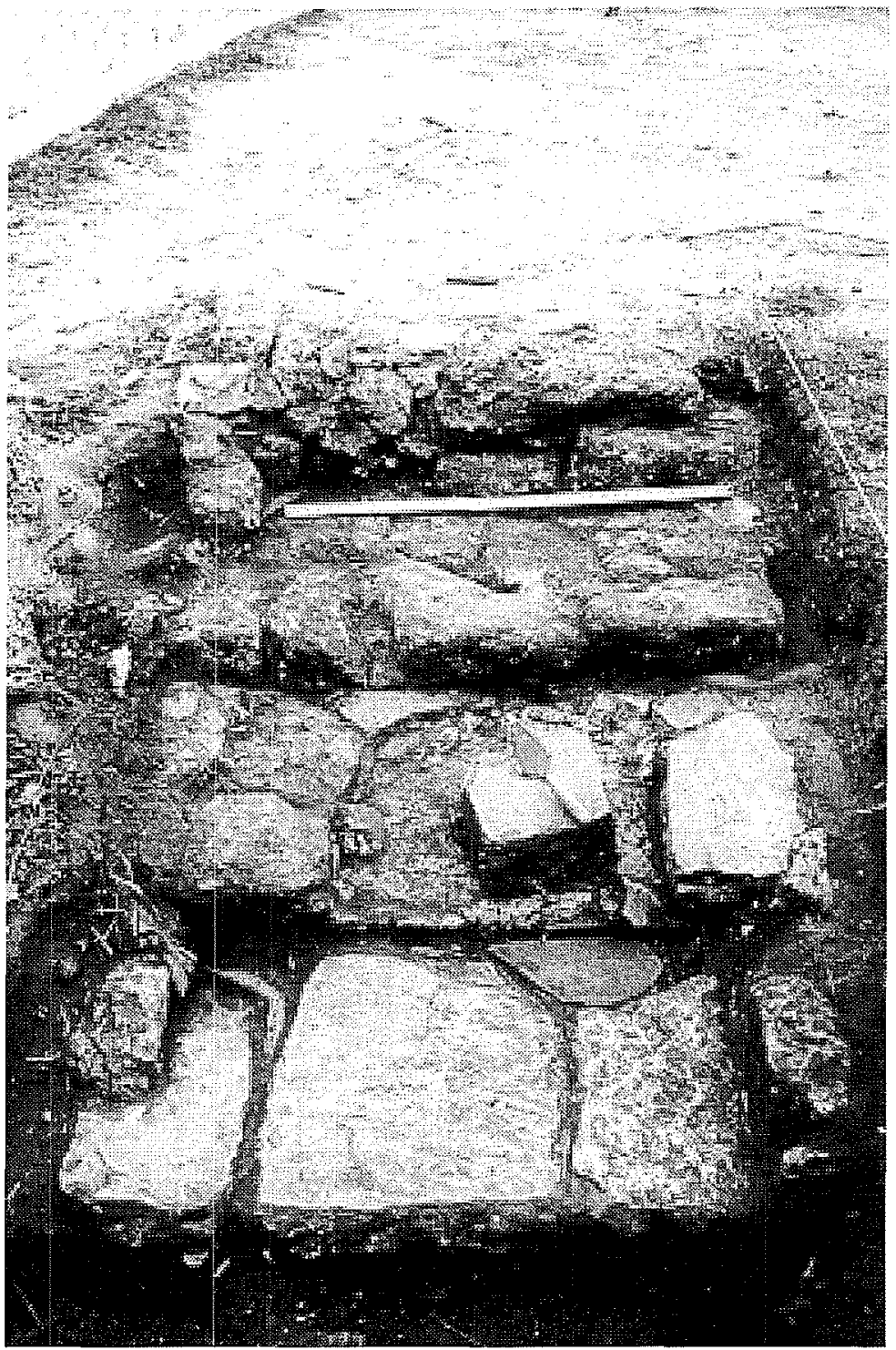

Figure 6. North Stairway, Area A.

\section{Unit A}

Unit A, measuring $3.5 \times 5 \mathrm{ft}$, was opened to the north of the south stairs, immediately adjacent to the triangular flagstone mentioned above. Only the eastern half of Unit A was excavated below the first six-inch level.

The soils in Unit A can be divided into four distinct zones based on observed differences in soil color and texture (Figure 7). Zone 1 is a grayish-brown, loose sandy clay with small gravels (with maximum diameters of half an inch). Within Zone 1 was a sand lens (Zone 1a) approximately three inches thick extending into Unit B. Zone 2 consisted of a four-inchthick layer of silty clay similar in color to Zone 1 . Zone 3 is a 20 - to 30 -inch-thick layer of very dark brown, blocky clay loam containing gravels up to four inches in diameter. Zone 3 also contained several pieces of shaped sandstone, presumably associated with the ca. 1930s reconstruction. Zone 4 consisted of a very light brown, firm clay loam matrix with grey, ashy mottling. Zone 4 was confined to the south half of Unit A at 36 inches below datum and is approximately six inches thick, sloping down towards the middle of the acequia. Unit A was excavated to a depth of 42 inches below datum.

\section{Unit B}

Unit B was $5.5 \times 5 \mathrm{ft}$. As with Unit A, excavation of Unit $B$ was limited to the east half of the unit after the first six-inch level. The soil zones in Unit B generally correspond to those mentioned above for Unit A. Zone 1a extended into Unit B about 12 inches. The Zone 2 identified in Unit A tapered off approximately 12 inches into Unit $B$ as well. In the northern half of Unit B, 15 inches below datum, was a lens of sandy clay with a high gravel content approximately 18-20 inches across (Zone 3a). Zone 4 was about 18 inches higher in Unit B than in Unit A, about 18 inches below datum. Zone 4 dips sharply toward the center of the acequia to the south. Overlying Zone 4, where it ends in the unexcavated portion of Unit B, is a light grey, firm clay loam containing small limestone gravels (Zone 4a). This level was differentiated from Zone 4 by its slightly darker color and the absence of the gray, ashy mottling present in Zone 4 . At the northern margin of Unit B, Zone 4 was approximately 14 inches thick. Unit $B$ was excavated to a depth of 42 inches below datum.

\section{Unit $C$}

Unit $C$ originally extended the width of the bottom stair of the north stairs, between Unit B and the stairs, making it 18 inches wide and 48 inches long. 
San Jose' Gristmill

Acequia between the stairs

East wall profile

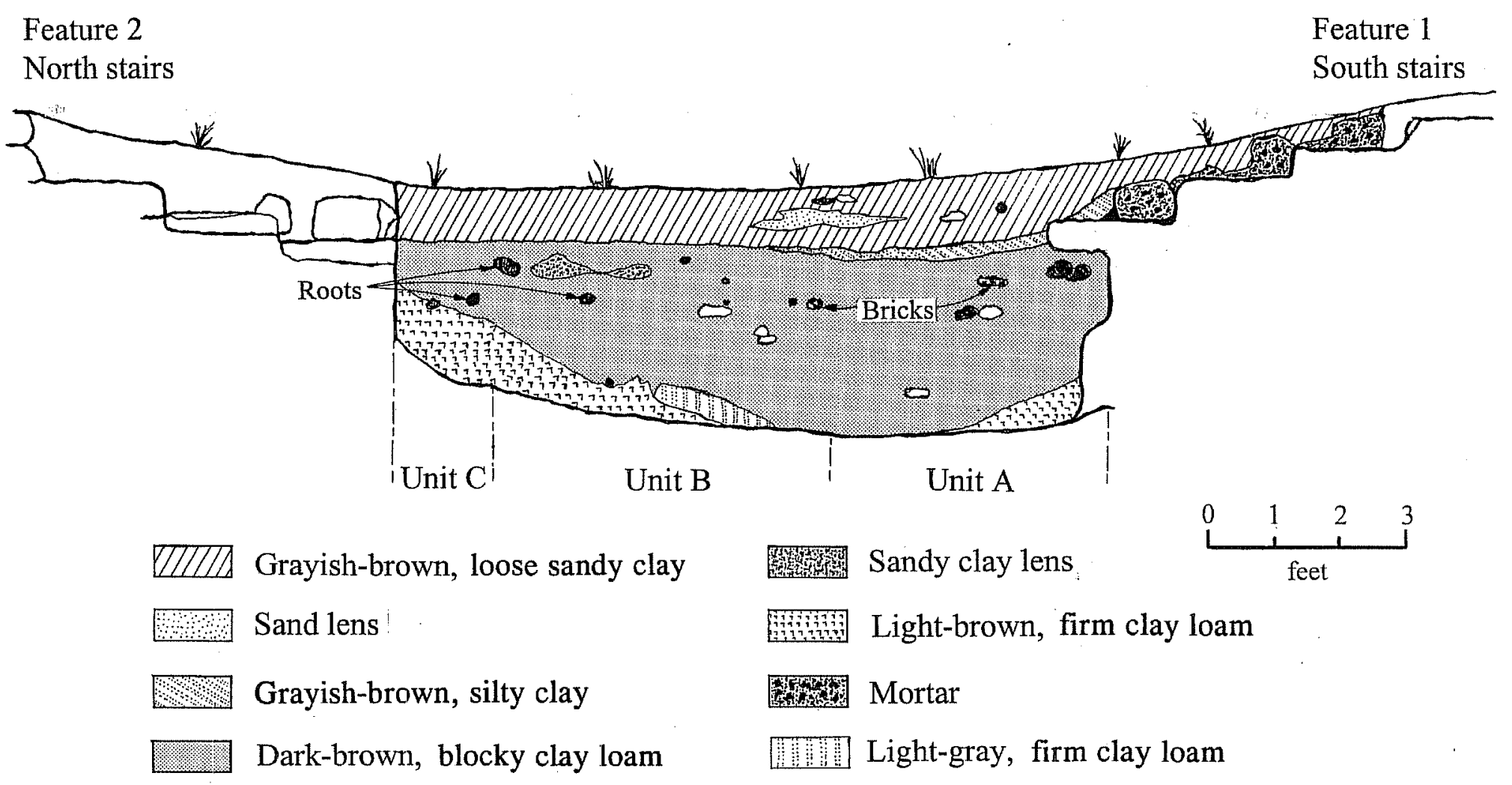

Figure 7. Profiles of excavation units. 
Only soil Zones 1, 3, and 4, are present in the profile of Unit C. Zone 1 was about 12 inches thick in Unit $\mathrm{C}$, as it was in Units A and B. Zone 3 was only about 8-12 inches thick in Unit C. The top of Zone 4 was identified at 18 inches below datum was about 12 inches thick. The top of the underlying caliche bedrock dipped to the south and was identified at 27 inches below datum in the northern profile of Unit C, and at 36 inches beneath datum in the southern profile. The southern portion of Unit $\mathrm{C}$ was excavated to a final depth of 36 inches below datum.

\section{Area B (Features 3, 4, and 5)}

Area B was centered around the stone-lined sluice leading from the acequia to the forebay (Figure 8). Excavation of the sluice was undertaken to determine its association with the acequia and existence of any unknown structures related to the operation of the mill itself. An arbitrary datum was established along the west wall of the sluice (584.15 ft amsl).

Two soil zones were identified in the sluice. Zone 1 consisted of approximately four inches of fill deposited since the WPA restoration. Zone 2 (16 inches below datum) was a hard-packed, light tan clay, mottled with slightly darker granular, sandy clay. Zone 2 was excavated to a depth of 36 inches below datum. There was no evidence of any Colonial-era structures in this underlying level.

Remnants of a wall, Feature 3, were observed running perpendicular to the west wall of the sluice. The top of this wall was cleaned, and excavation on both the north and south sides (Units E and F, respectively) was undertaken to determine how much, if any, of the structure remained in situ. An alignment of limestone cobbles adjacent to Units $\mathrm{E}$ and $\mathrm{F}$ was designated Feature 4. The datum established for the sluice was used for both Units E, F, and H. Feature 5 consisted of a low, semicircular wall abutting the eastern wall of the sluice.

\section{Unit E}

Unit $E$ was $1 \times 8 \mathrm{ft}$, exposing the south side of Feature 3. The first soil zone was hard-packed, pea-size gravels approximately $3-5$ inches in depth. Zone 2 is a gray to light brown sandy loam containing a large amount of stream-rolled limestone and quartzite gravels less than two inches in diameter. This zone continues to about

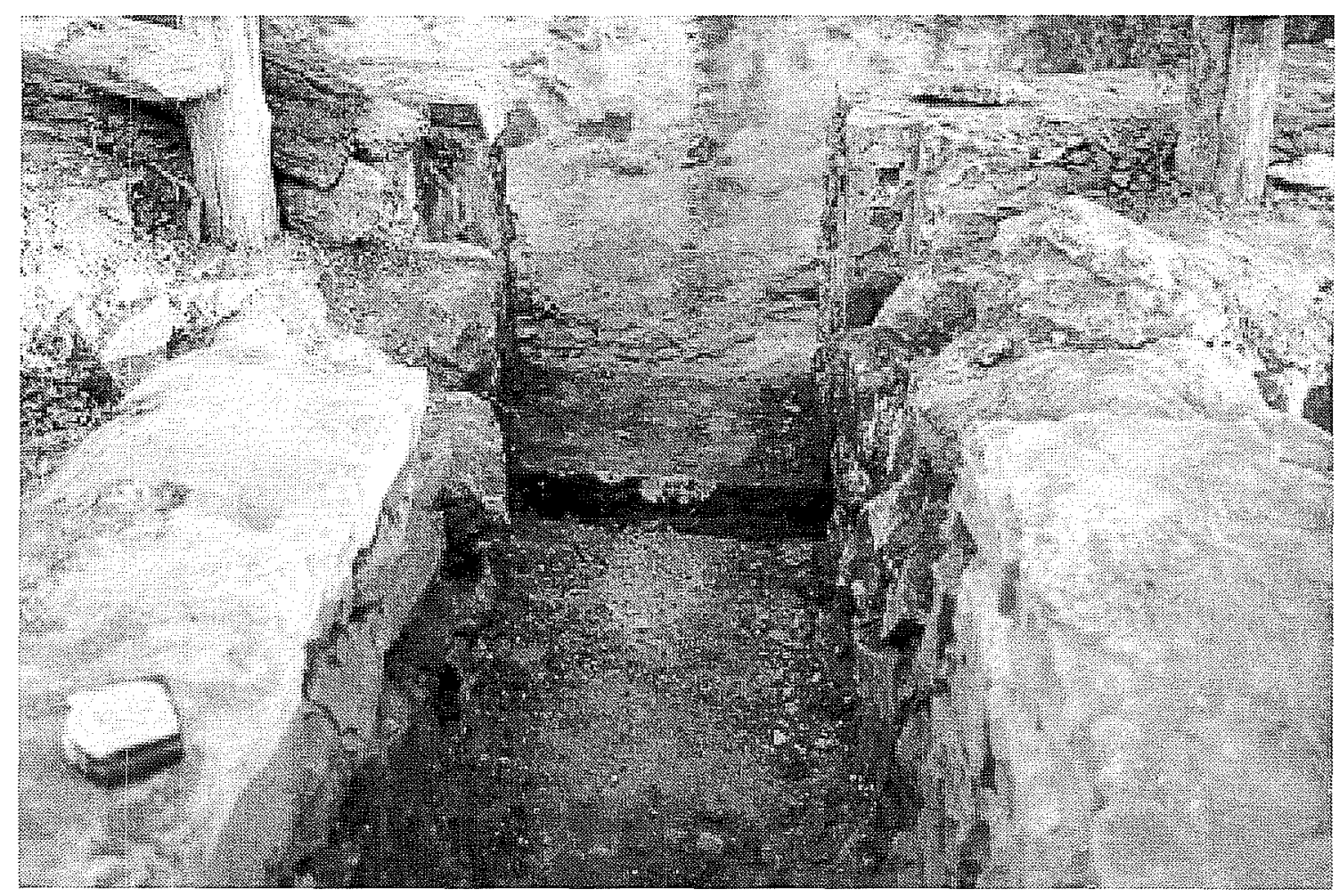

Figure 8. Excavated sluice, looking north toward the mill. 
20 inches below datum. Zone 3 is similar to Zone 2, except for the absence of the rounded gravels. Zone 3 continues to a depth of 42 inches below datum. Where the wall in Unit $E$ abuts the west wall of the sluice, its base was 36 inches below datum. The wall becomes shallower to the west. At its westernmost point, the base of the wall is only $2-4$ inches below the surface. Unit $E$ was excavated to a depth of 42 inches.

The wall itself was constructed of limestone cobbles held in place with a loose, sandy mortar. There appeared to be no formal coursing of the mortared cobbles.

\section{Unit F}

Unit $F$ exposed the north side of Feature 3 and the area between the wall and the reconstructed forebay. Zone 1 of this unit corresponds to Unit E, Zone 1 . Zone 2 was a dark gray sandy loam without the gravels present in Unit E, Zone 2. In the eastern portion of this unit was a large limestone rock ( 24 x 18 inches) immediately adjacent to the wall, 6-8 inches below datum. To the west of the large rock, Zone 2 continues to a depth of $8-12$ inches below datum. Zone 3 begins at 12 inches below datum. The soil matrix in Zone 3 is basically the same as the previous level, but the soil is mottled with a large amount of a chalky substance and limestone cobbles from 3-6 inches in diameter. Unit $F$ was excavated to a depth of 24 inches below datum.

\section{Unit $G$}

The alignment of limestone cobbles to the west of Units $E$ and $F$ was uncovered to a depth of 12 inches to determine if there was any association with the wall described above. The alignment was limited to the surface and the stones are most likely remnants of the lining of a walkway constructed by Smith in the 1930s (Figure 2).

\section{Unit $H$}

Unit $\mathrm{H}$, measuring $2.5 \times 3 \mathrm{ft}$, was adjacent to the east wall of the sluice. The northern edge of the unit is delineated by the south wall of Feature 5 . Zone 1 is similar to Zone 1 in Unit E, with pea-sized gravels to a depth of 3-5 inches below the surface. Directly under this zone was a layer of sandy clay mixed with limestone cobbles up to six inches in diameter. This second zone continued to the bottom of the wall, 20-23 inches below the top of the wall. As with Feature 3, the limestone cobbles were mortared with a loose, sandy mortar and showed no formal coursing (Figure 9).

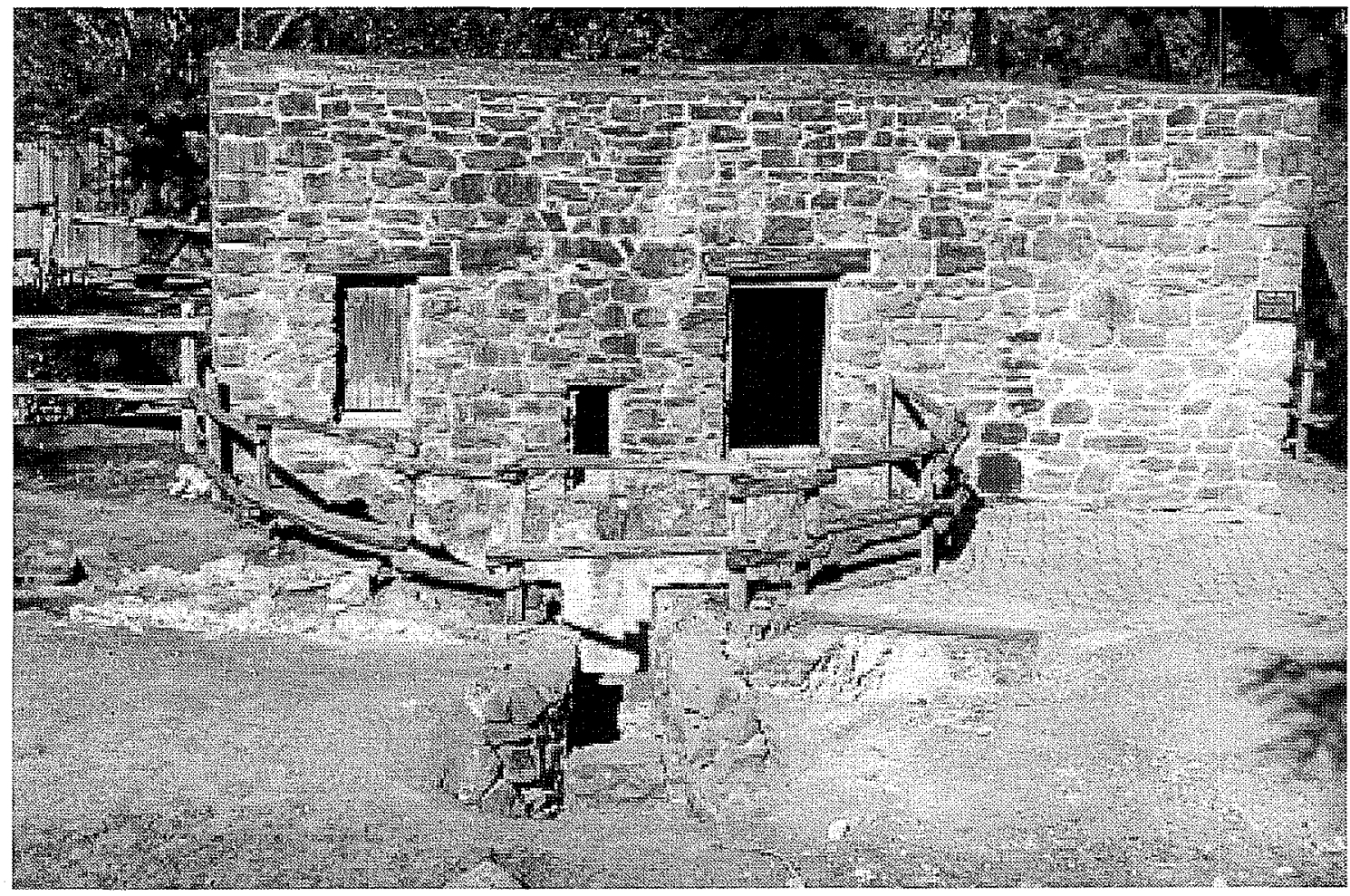

Figure 9. Area $B$, after excavation, looking north from the mission wall. 


\section{Area D}

Area D consists of the vaulted turbine room below the millroom. No artifacts were collected from the area. Excavations in Area D were limited to exposing the flagstone floor. Schuchard (1934:9) noted the presence of the floor during the reconstruction excavations, but it is unclear if it was constructed in the Colonial or post-Colonial period. Limited areas around the mill wheel were also cleaned to identify intact portions of the reconstruction-era wooden crossbeam.

\section{Area $\mathbf{E}$}

A 2-x-3-ft area within the structure referred to as the tanning vat/sugar processing area was cleared of material deposited since the ca. 1930s reconstruction.

\section{Unit D}

Unit $\mathrm{D}$ is a $5-\mathrm{x}-5-\mathrm{ft}$ unit which includes both sides of an north-south alignment of sandstone blocks mortared with Portland cement. Excavation of this unit was undertaken to determine if this alignment is Colonial in origin. Unit $\mathrm{D}$ was excavated in six-inch levels to a depth of 12 inches before we determined that the alignment was limited to the surface.

\section{Area F}

Area F included the area to the north of the sandstone wall at the north end of the mill race. This area was not screened and no artifacts were collected. This area was excavated to determine if the sandstone lining of the mill race continued past the wall. Excavation showed that the sandstone lining terminated three feet from the north side of the wall.

\section{Artifacts}

Because of the level of disturbance and amount of fill removed from the area in the reconstruction of the gristmill in the 1930s, little can be learned from the artifacts recovered in our excavations. Most deposits are a mix of Colonial, post-Colonial, and modern items. Very little material was recovered in unmixed contexts from any of the areas. Only in the lower levels of Area A (Units A, B, and C) were discrete components observed.

In the upper levels of Area A artifact deposits were quite mixed. Spanish colonial Goliad and majolica sherds were found in direct association with post-Co-

Table 1. Ceramic Artifacts from Units A and B (all levels)

\begin{tabular}{|c|c|c|c|c|}
\hline Category & Subcategory & Type & Count & $\begin{array}{l}\% \text { of } \\
\text { Total }\end{array}$ \\
\hline \multicolumn{5}{|l|}{ Unrefined } \\
\hline & Unglazed & Goliad & 9 & 18 \\
\hline & Lead-glaze & & 3 & 6 \\
\hline & Tin-glaze & Majolica & 3 & 6 \\
\hline & Total & & 15 & 31 \\
\hline \multicolumn{5}{|l|}{ Refined } \\
\hline & Whiteware & & & \\
\hline & & Undecorated & 22 & 45 \\
\hline & & Handpainted & 3 & 6 \\
\hline & & Sponge & 1 & 2 \\
\hline & & Transfer & 1 & 2 \\
\hline & & Edgeware & 2 & 4 \\
\hline & & Spatter & 2 & 4 \\
\hline & & Banded slip & 2 & 4 \\
\hline & & Luster & 1 & 2 \\
\hline & Total & & 34 & 69 \\
\hline & Grand Total & & 49 & 100 \\
\hline
\end{tabular}


lonial decorated and undecorated whitewares, as well as with many items of modern origin. The modern items included personal items such as coins and fragments of plastic barrettes, a small plastic dove, and pieces of star-shaped colored foil. Other modern items included wire nails; screws; fence staples; small fragments of sewer pipe; a small fragment of ceramic tile; bottle caps; aluminum can pull tabs; plastic coated wire; metal wire; brown, green, and white bottle glass; and the base of a Christmas tree lightbulb.

Only in the levels below the bottommost step of each stairway (18-42 inches below datum) do artifacts from before the twentieth century occur in an unmixed context (Tables 1 and 2). In addition to the ceramic artifacts recovered from Levels 4, 5, and 6 in Unit A and Levels 3 and 4 in Unit B (all within soil Zone 3 ), there were small quantities of hand-blown glass fragments, heavily weathered animal bone, and small unidentifiable fragments of metal. Unit A, Level 4 contained the base of a green hand-blown glass bottle, two thinner glass fragments of the same color and one fragment of bleached, hand-blown glass. The right carpal of a cow (Bos taurus) and four fragments of bone $(29.76 \mathrm{~g})$ from another, unidentified, large mammal were also recovered. The ceramics included one sherd of blue on white majolica, one sherd of lusterware, and seven sherds of undecorated whiteware.
Unit A, level 5, contained one cut nail and one fragment of bleached, hand-blown glass. Excavation also recovered the lower left molar of a cow (Bos taurus) and five small fragments of bone $(8.7 \mathrm{~g}$ ) from an unidentified large mammal. The phalanx of a horse or donkey (Equus sp.) was also recovered. Recovered ceramics included one sherd of blue on white majolica, one sherd of handpainted whiteware, and five sherds of undecorated whiteware.

Unit A, level 6, contained 28 fragments ( $90.14 \mathrm{~g}$ ) of unidentified large mammal bone. No glass was recovered from this level. One sherd of sponge-decorated whiteware and one sherd of undecorated whiteware were excavated from this level.

Unit B, Level 3, contained one fragment of bleached, hand-blown glass and one fragment of green bottle glass similar to that recovered in Unit A, level 4. Two fragments of unidentifiable bone were also recovered from this level. This level contained one sherd of transfer-decorated whiteware and one sherd of undecorated whiteware.

Unit B, level 4, contained two fragments of handblown green bottle glass similar to those found in the previous level and five fragments of bleached, handblown glass. There was also a fragment of Spanish Colonial brick recovered. Faunal remains consisted

Table 2. Ceramic Artifacts from Unmixed Contexts

(Unit A, levels 4, 5, and 6 and Unit B levels 3, 4, and, 5)

\begin{tabular}{|c|c|c|c|c|}
\hline Category & Subcategory & Type & Count & $\begin{array}{l}\% \text { of } \\
\text { Total }\end{array}$ \\
\hline \multicolumn{5}{|l|}{ Unrefined } \\
\hline & Lead-glaze & & 1 & 4.3 \\
\hline & Tin-glaze & Majolica & 2 & 8.7 \\
\hline & Total & & 3 & 13.0 \\
\hline \multicolumn{5}{|l|}{ Refined } \\
\hline & Whiteware & & & \\
\hline & & Undecorated & 15 & 65.4 \\
\hline & & Handpainted & 2 & 8.7 \\
\hline & & Sponge & 1 & 4.3 \\
\hline & & Transfer & 1 & 4.3 \\
\hline & & Luster & 1 & 4.3 \\
\hline & Total & & 20 & 86.6 \\
\hline & Grand Total & & 23 & 100 \\
\hline
\end{tabular}


of the left carpal and two lower molars of a cow and nine fragments $(18.80 \mathrm{~g})$ of unidentified large mammal bone (two of which were burned). Ceramics from this level included one sherd of lead-glazed earthenware, one sherd of handpainted whiteware, and one sherd of undecorated whiteware.

The only other areas with significant artifact recovery were Units $\mathrm{E}$ and $\mathrm{H}$ in Area B. However, as with the upper levels of Area A, artifacts from divergent time periods were found in close association. A onequart paint can was excavated from 18 inches below datum in Unit $\mathrm{E}$ and one piece of undecorated whiteware was recovered at the same level. In Unit $\mathrm{H}$ an eight-inch piece of barbed wire, machine-made bottle glass, and a thin sandstone block covered in asphalt were found in close association with the medial fragment of a chert biface and the scapula of a large mammal.

\section{Discussion}

Much of the excavation in and around the gristmill involved the removal of the modern detritus deposited during the last 60 years. The cleaning of Areas $C$, $\mathrm{D}$, and $\mathrm{E}$ was a straightforward exercise and does not require more comment than has been presented above. The features excavated in Areas A and B present us with issues which are not so easily defined. We can present a number of hypotheses regarding the origin and function of these features; however, a conclusive explanation is not available given both the lack of archival data and the degree of disturbance associated with the excavation and reconstruction of the mill by Smith and Schuchard in the 1930s. While these problematic areas do not affect the proposed refurbishing of the mill, they do raise some interesting questions which should be addressed.

It was thought that the stairs identified in Area A were Colonial in origin; however, excavation and archival research strongly support a modern origin. Clark states as much, and also shows the stairs on a site map with the date "1933" in parentheses (1978:54, Figure 3). While it might be assumed that Clark found evidence for the origin of the stairs in Smith's field notes, this is never explicitly stated in Clark's report. Figure 3 shows the stairs as they looked during the 1930s reconstruction. It is not clear in the photo if the stairs are a reconstruction of a preexisting Colonial feature, or an entirely new construction built by Smith. The associations of the soils in the east wall of Area $A$ (Units A, B, and C) with the stairs and the artifact content of these soils support the latter.

The profile of contiguous Units A, B, and C (Figure 5) shows the original position of the acequia. Zone 4 in the profile represents the surface of the acequia. This designation is supported by the artifact content of Units $\mathrm{A}, \mathrm{B}$, and $\mathrm{C}$. Zone 1, immediately overlying the stairs, contained artifacts from both modern and post-Colonial eras. Below Zone 1, no modern artifacts were recovered in association with post-Colonial or Colonial ceramics. The soil in Zone 3 apparently represents fill accumulated in the acequia between the early nineteenth century and the 1930s. The absence of artifact mixing in Zone 3 leads us to believe that the cleaning of the acequia in the 1930s did not extend deep enough to expose the original limits of the ditch. Zones 3 and 4 also extend well underneath the south stairs, leading us to conclude that the stairs are not contemporaneous with the original acequia. Based on the artifactual and stratigraphic evidence then, the stairs were apparently constructed on what the WPA assumed was the edge of the acequia, when in reality the acequia was significantly deeper and somewhat to the south.

Features 3 and 5 are the most puzzling of the structures excavated at the gristmill. Several photographs give an excellent idea of the original physical relationship of these features. In Figure 4, Feature 5 is the remaining portion of the east side of the semi-circular wall in the center of the photo. The concave side faces the forebay. Feature 3 can be seen running perpendicular to the west side of the semi-circular wall. There appears to be a matching wall opposite Feature 3. Comparing our excavation results with Figure 3, the amount of disturbance to this structure is readily apparent. Unfortunately, while showing the original relationship of the features, these photos give no clues to their construction date or function, although the mortar was a soft lime usually associated with the eighteenth and first half of the nineteenth century. In the absence of any definitive answers, we offer several alternative hypotheses on the origin and function of the features. 
The acequia may have been dammed below the mill, allowing the water to pool in the area directly in front of the forebay. In this scenario the wall would have served to stabilize the bank on the mill side of the pool. Support for this hypothesis comes from the elevations taken during our excavations.

Recorded elevations show that the sluice, as reconstructed in the 1930s, is $2.22 \mathrm{ft}$ higher than the bottom of the acequia during the Spanish colonial era. If the present-day elevation of the sluice is the same as it was in the $1790 \mathrm{~s}$, it may indicate that dammed water was indeed pooled in front of the forebay. As the level of the pool rose, it would have reached a level high enough to flow into the forebay. This arrangement would have been an effective means of keeping water out of the mill when it was not in use (without having to use both a dam and a gate for the sluice), as well as keeping out sediment.

If the above assumptions about the elevation of the sluice are changed, then we are presented with a different set of hypotheses. Clark (1978:41) states that Smith added $3.5 \mathrm{ft}$ to the forebay walls in his reconstruction. If this is the case, then the top of the forebay was considerably lower than the present elevation. In this case the wall may have served as a means to control the force of water as it entered the sluice and forebay. However, Figures 3 and 4 show no means for water to enter the forebay through the wall, and the relevant portion of the wall was destroyed in the reconstruction.

James Ivey (personal communication 1997) believes the wall may represent the remnants of a lime kiln originally built in the 1740s. Construction and subsequent use of the lime kilns created a large gully which was then incorporated into the mill, built in the 1780s. However, evidence from previous excavations (Fox et al. 1970:Figure 3) suggests the lime kilns were built into a preexisting gully and the construction and utilization of the lime kilns did not in itself create the gully. In addition, the identification of this wall as the remnant of the upper portion of a lime kiln still leaves no way for water to enter the forebay through the wall. As above, with the relevant portion of the wall removed in the reconstruction of the mill, we are left with little evidence to prove or disprove either hypothesis.
Water may have entered the forebay from a sluice coming in from more of an oblique angle to the acequia, rather than the perpendicular direction in the 1930s reconstruction. The wall may be the remnant of an east-to-west-oriented sluice. If the water did enter from a more westerly direction, then a Colonial origin for Features 3 and 5 is better supported, but the function of the semi-circular wall is still unclear.

There is some disagreement as to the possibility of a dam in the vicinity of the gristmill. The 1794 inventory of the mission states "ytem un molino para moler trigo en corriente con la falta de una cortina," which translates to "a watermill for grinding wheat that is operated by a running stream but no dam" (Habig et al. 1983:131). Clark (1978:40-41), however, translates the same passage as "a water-powered mill to grind wheat, lacking a curtain." Clark believes that the "curtain" is a reference to the open north side of the vaulted turbine housing. Cortina can refer to a curtain, shade, or screen, but also may refer to "part of a wall or rampart which lies between two bastions" (Velazquez et al. 1943:182). Which interpretation is correct is still open to debate.

There are several possible functions for Features 3 and 5 that point to a post-Colonial origin. The first of these may involve post-Colonial water rights. The wall may have served to prevent water from flowing through the unused mill and out the mill race into the fields between the mission and the San Antonio River. However, we have found no support for this hypothesis in the post-Colonial archives.

The wall also may have been erected to keep livestock from falling into the deep forebay or the lower parts of the mill. As it is likely that parts of the mill were still visible in the mid-nineteenth century (see the above discussion of Father Hoermann), it is possible that injury to livestock may have been a concern of nineteenth-century farmers and ranchers.

Finally, there is the possibility that the wall was built by WPA work crews during the reconstruction as a means of keeping debris out of the forebay and mill while excavations were taking place. Without access to Smith's field notes this hypothesis cannot be supported. 
Presented with so many hypotheses, all lacking supporting archival or archaeological evidence, it is inadvisable to make any definitive statements about the origin or function of Features 3 and 5. Further excavation is unlikely to answer all but one of the alternative hypotheses: close monitoring of construction during the proposed refurbishment of the gristmill may reveal information on the location of the original sluice.

\section{Conclusions and Recommendations}

The profile of Area A shows the limits of the original acequia to be deeper than was assumed by the WPA restoration crew. Because no significant archaeological deposits were found in Area A, continued archaeological work, other than monitoring of future construction, is not recommended.

Based on the results of our excavation, the stone stairways on the north and south banks of the ditch are thought not to be Colonial in origin. All evidence points to the construction of the steps taking place during the reconstruction of the mill in the 1930s.

Cleaning and excavation of the sluice leading from the acequia into the forebay in Area B found no significant archaeological features within the limits of the sluice itself. The remnants of the slide gate constructed at the juncture of the sluice and the forebay in the 1930 s was noted during our investigations. The function or origin of the walls adjacent to the east and west sides of the sluice (Features 3 and 5) could not be determined based on the available information. While, as noted above, these features may have had some function in the operation of the mill during the Spanish colonial occupation, it is unlikely that the proposed construction will have any affect on the remaining structures. However, because of the lack of clarity surrounding the origin of these features and their relationship to the acequia and the gristmill, monitoring of future construction in this area is recommended.

Investigations around the tanning vat/sugar mill (Area E) did not uncover evidence of additional structures associated with this feature. The area was heavily disturbed during the WPA excavations, so it is unlikely that intact deposits are still extant.

Cleaning of the vaulted turbine housing (Area D) did reveal that the original flagstone floor and a badly rotted wooden member underneath the mill turbine were still in situ. Monitoring of any construction involving disturbance of the flagstone floor is recommended. Intact deposits associated with the operation of the lime kilns that pre-date the gristmill may underlie the flagstone floor.

Excavation of Area $\mathrm{F}$ at the north end of the mill race showed that the sandstone lining did end just north of the sandstone wall which blocks the north end of the mill race. In addition, based on comparisons of photographs from ca. 1930 with the modern landscape, the soils in this area consist entirely of fill deposited since the 1930s. This area does not merit further investigation. 


\section{References Cited}

Bolton, H. E.

1915 Texas in the Middle Eighteenth Century. Publications in History, Volume 3. University of California, Berkeley.

Campbell, T. N., and T. J. Campbell

1985 Indian Groups Associated with Spanish Missions of the San Antonio Missions National Historical Park. Special Report, No. 16. Center for Archaeological Research, The University of Texas at San Antonio.

Chipman, D. E.

1992 Spanish Texas: 1519-1821. University of Texas Press, Austin.

Clark, J. W.

1978 Mission San José y San Miguel de Aguayo: Archeological Investigations, December 1974. Office of the State Archeologist, Report 29. Texas Historical Commission, Austin.

Clark, J. W., and E. R. Prewitt

1979 Archeological Test Excavations in an Area to be Affected by a Proposed Trench Drain West of the Granary: Mission San José State Historic Site (4l BX 3), Bexar County, Texas. Reports of Investigations 3. Prewitt and Associates, Austin.

Czibesz, P. L.

1955 Unknown Facts about Technical History in San Antonio. Manuscript on file. Daughters of the Republic of Texas Library, The Alamo, San Antonio.

Day, J. M.

1965 The Mississippi of Texas 1821-1850. Texana 3 (1):20-43.

Fox, A. A., and I. W. Cox

1991 Testing the San José Mission Acequia, San Antonio Missions National Historic Park, Bexar County, Texas. Archaeological Survey Report, No. 207. Center for Archaeological Research, The University of Texas at San Antonio.

Fox, D. E., K. L. Killen, and D. Scurlock

1970 Archeological Salvage at Mission San José, December 1969, April and August 1970. Texas Historical Survey Committee, Austin.

Habig, M. A.

1968a The Alamo Chain of Missions: A History of San Antonio's Five Old Missions. Franciscan Herald Press, Chicago.

1968b San Antonio's Mission San José, State and National Historic Site, 1720-1968. Naylor, San

Antonio 
Habig, M. A. (compiler)

1978 The San José Papers: The Primary Sources for the History of Mission San José y San Miguel de Aguayo from Its Founding in 1720 to the Present. Part I: 1719-1791. Old Spanish Missions Historical Research Library, Mission San José, San Antonio.

Habig, M. A., B. Leutenegger, and M. C. Casso

1983 The San José Papers: The Primary Sources for the History of Mission San José y San Miguel de Aguayo from Its Founding in 1720 to the Present. Part II: August 1791-June 1809. Old Spanish Missions Historical Research Library, Mission San José, San Antonio.

Hafernik, D., and A. A. Fox

1984 Archaeological Testing of Proposed Sewer Line Locations at Mission San José. Archaeological Survey Report, No. 138. Center for Archaeological Research, The University of Texas at San Antonio.

Hard, R. J., A. A. Fox, I. W. Cox, K. J. Gross, B. A. Meissner, G. Mendez, C. L. Tennis, and J. Zapata 1995 Excavations at Mission San José y Miguel de Aguayo, San Antonio, Texas. Archaeological Survey Report, No. 218. Center for Archaeological Research, The University of Texas at San Antonio.

Henderson, J., and J. W. Clark

1984 Test Excavations at the Acequia and Other Features at Mission San José, Bexar County, Texas. Publications in Archeology 25. Texas State Department of Highway and Public Transportation, Austin.

Hoermann, P. A. S.

1932 The Daughter of Tehuan, or Texas of The Past Century. Standard, San Antonio.

Ivey, J. E., M. B. Thurber, and S. Escobedo

1990a Of Various Magnificence. The Architectural History of the San Antonio Missions in the Colonial Period and the Nineteenth Century. Volume One. National Park Service Professional Papers No. 11, Santa Fe. Draft on file at the Center for Archaeological Research, The University of Texas at San Antonio.

1990b Of Various Magnificence. The Architectural History of the San Antonio Missions in the Colonial Period and the Nineteenth Century. Volume Two. National Park Service Professional Papers No. 11. Santa Fe. Draft on file at the Center for Archaeological Research, The University of Texas at San Antonio.

Jones, O. L., Jr.

1979 Los Paisanos-Spanish Settlers on the Northern Frontier of New Spain. University of Oklahoma Press, Norman.

Leutenegger, B., and M. C. Casso

1990 The San José Papers, Part III: July 1810-February 1824. Old Spanish Missions Historical Research Library, Mission San José, San Antonio.

Roberson, W., and T. W. Medlin

1976 San José Mission State Historic Site, Archeological Testing 1974 and 1976, edited by I. D. Ing. Archeological Report, No. 23. Texas Parks and Wildlife Department, Historic Sites and Restoration Branch, Austin. 
Schuchard, E.

1934 Old Mill of San José Mission. Schuchard Collection, Daughters of the Republic of Texas Library, the Alamo, San Antonio.

Schuetz, M. K.

1980 The Indians of the San Antonio Missions, 1718-1821. Ph.D. Dissertation. The University of Texas at Austin.

Smith, H. P., Sr.

1935 Old Mill of San José Mission. Plaza Hotels: Plaza Parade, September, pp. 10, 13.

Tennis, C. L.

1997 Archaeological Testing of the Southeast Gate at Mission San José, San Antonio, Texas. Archaeological Survey Report, No. 252. Center for Archaeological Research, The University of Texas at San Antonio. In preparation.

Velazquez de la Cadena, M., E. Gray, and J. L. Iribas

1943 A New Pronouncing Dictionary of the Spanish and English Languages. Wilcox and Follet, New York. 
. 